Equilibrium Res Vol. 63(4) 366 367, 2004

\title{
トピックス
}

\section{最近の赤外線 CGD カメラについて}

池田 卓生（鼓ヶ浦こども医療福祉センター耳鼻咽喉科）

\section{はじめに}

赤外線 $\mathrm{CCD} カ$ カは，今やめまい診療に打い て重要かつ不可欠なものとなっているが，現在 様々な機種が多くのメ一カーから販売され，選択 肢も増えてきた。そこで今回，最近の赤外線 CCD カメラ事情についてまとめてみた。

\section{フレンツェル眼鏡の代わりとして}

最も多くの需要があり，最も多くの機種が販売 されているのが，従来のフレンッェル眼鏡の代わ りとしての赤外線 CCD カメラである (赤外線フ レンツェル眼鏡と呼ばれるのもこのためである)。 最近の傾向は，低価格化と液晶モニターとの組み 合わせである。価格は，以前の60７0万円台から 20〜30万円台が主流となり，液晶モニターは，場 所を取らず往診に使いやすいようにするために ゴーグルに取り付けられたり，患者に画像を提示 しやすいように付属するようになっている。

しかし、ゴーグル自体や CCD カメラの性能に ついては, あまり変化はない。ゴーグルの重量に ついては, 約 $150 \mathrm{~g}$ という軽量そデルもあるが， 主な機種は約 300〜 400 g である。最近では良性 発作性頭位めまい症に対する理学療法を行らこと が多くなっているため様々な頭位で眼振を観察す るが，眼球が画面から外れてしまったり，焦点が 合わず虹彩紋理が十分観察できないなどの問題を しばしば経験する。また，ゴーグルの形状が患者 に合わず，鼻背に跡が残ったり，痛みを訴えられ る場合もある。今後は，より小型軽量で患者に負 担をかけず，ケーブル類が邪魔にならないゴーグ ルの開発が望まれる。

CCD カメラの性能については, 約 $25 〜 30 万$ 画 素が主流で，高画質を諨ったもので約40万画素で ある。技術的に安易に比較できるるのではないが, 携帯電話でさえメガピクセルで動画を撮れる時代 である。虹彩紋理まで明瞭に観察しながら検查す るためにも，少なくとも40万画素クラスでゴーグ ルと同様に小型軽量化された CCD カメラが期待
される。

画像の記録方法については変化が見られてい るり。以前はビデオに録画されるだけであったが， 最近では DVDレコーダーやハードディスクレ コーダーが普及し利用されるよらになっている。 また，パコンへ直接録画することも容易になっ ている。耳鼻咽喉科は赤外線 CCD カメラ以外に も画像を扱うことが多い診療科である。今後，外 来に溢れてきた画像データをどのようにファイリ ングしていくかが課題である。

\section{ENG の代わりとして}

平衡機能検查では, ENGの代わりとして赤外 線 CCD カメラとパソコンと組み合わせて眼球運 動を画像解析する力法が用いられるようになって きた（最近，この方法は VOG: Video-Oculography と総称されることが多くなった)。水平・垂直・ 回旋の 3 成分を解析可能な機種は 2 社から, 水 平・垂直の 2 成分を解析可能な機種はさらに多く のメーカーから販売されている。2 成分解析の機 種には，角度センサーを付けて VOR の解析を容 易にしたもの，急速眼球運動を記録可能にしたも の、ゴーグルに視覚刺激スクリーンを内蔵したも のなどがあり，それぞれ特徵を競っている。しか し解析内容については，基本的には波形を表示し て速度を計算することが主である。今後ここの VOG が広く発展していくかどらかは，めまい診 療のベテランが ENG 記録から様々な情報を読み 取るよらに，パソコンを用いて波形データからど れだけ多くの情報を導き出せるかが鍵になると考 える。

また VOG は，動物実験にも応用されるように なっている23)。動物での定量的な前庭機能の評 価は従来技術的に難しい面もあったが，VOG に よって解析が容易に行えるようになった。動物倫 理的にも非侵襲的なVOGには利点があり, 今後, 動物実験に打いて子眼球運動の記録・解析の主流 になっていくと考えられる。 


\section{文献}

1 ) 池田卓生：日常外来での画像作成・記録 眼 振記録. JOHNS 19: 1706-1710, 2003

2 ) 堀池 修, 池田卓生, 下郡博明, 他: モルモッ 卜眼球運動画像解析法の開発. Equilibrium
Res 61: 28-33, 2002

3) 村井紀彦, 过 純, 堀 龍介, 他: マウス に扣壮る一側内耳破壊後の前庭眼反射の代

償. Equilibrium Res 61: 40-44, 2002 